Volume 11, Issue 12, December 2020, pp. 237-246. Article ID: IJM_11_12_023

Available online at http://iaeme.com/Home/issue/IJM?Volume $=11 \&$ Issue $=12$

Journal Impact Factor (2020): 10.1471 (Calculated by GISI) www.jifactor.com

ISSN Print: 0976-6502 and ISSN Online: 0976-6510

DOI: 10.34218/IJM.11.12.2020.023

(C) IAEME Publication

Scopus Indexed

\title{
ENTREPRENEURIAL TRAITS AND ANTECEDENTS OF LOW-INCOME HOUSEHOLDS IN KELANTAN, MALAYSIA
}

\author{
Mohd Nor Hakimin Yusoff \\ Associate Professor, Faculty of Entrepreneurship and Business, \\ Universiti Malaysia Kelantan, Malaysia \\ Fakhrul Anwar Zainol \\ Associate Professor, Faculty of Business and Management, \\ Universiti Sultan Zainal Abidin, Malaysia \\ Mohammad Ismail \\ Associate Professor, Faculty of Entrepreneurship and Business, \\ Universiti Malaysia Kelantan, Malaysia
}

\author{
Abdullah Al Mamun \\ Research Fellow, Global Entrepreneurship Research and Innovation Centre (GERIC), \\ Universiti Malaysia Kelantan, Malaysia \\ Tengku Mohd Azizuddin Tuan Mahmood \\ $\mathrm{PhD}$ Candidate, Faculty of Entrepreneurship and Business, \\ Universiti Malaysia Kelantan, Malaysia \\ Rooshihan Merican Abdul Rahim Merican \\ Faculty of Entrepreneurship and Business, \\ Universiti Malaysia Kelantan, Malaysia
}

\begin{abstract}
This study aims to determine the distribution of entrepreneurial traits across districts, gender, education, occupations, and experience levels in Kelantan, Malaysia. This study employed a cross-sectional approach, by which quantitative data were collected from 800 low-income household heads in Kelantan, Malaysia. It was found that the distribution of entrepreneurial traits was the same across genders. However, the findings reported a significant difference in the distribution of entrepreneurial traits across districts, education levels, occupations, and experience levels. Policymakers should, therefore,, focus on ways to cultivate and increase the level of entrepreneurial traits among the low-income household heads, especially in
\end{abstract}


the district of Jeli and those who have never attended school, fishermen, and those who reported having no experience, since these groups scored the lowest indicating a lack of entrepreneurial traits.

Key words: Entrepreneurial Traits; Low-Income Household.

Cite this Article: Mohd Nor Hakimin B Yusoff, Fakhrul Anwar Zainol, Mohamad B Ismail, Abdullah Al-Mamun, Tengku Md Azizudin Tuan Mahmood and Rooshihan Merican Abdul Rahim Merican, Entrepreneurial Traits and Antecedents of LowIncome Households in Kelantan, Malaysia, International Journal of Management, 11(12), 2020, pp 237-246.

http://iaeme.com/Home/issue/IJM?Volume=11\&Issue=12

\section{INTRODUCTION}

Entrepreneurship is known as the ability of an individual or a group of people to discover opportunity and utilize it to bring benefit to society, and in return, be successful in their organization. This has made entrepreneurship is regarded as at the frontage of a country's economic and social development for the creation of wealth and distribution chains. Entrepreneurship is vital to economic growth and is accountable for the expansion and promotion of all types of productive activities in the global economy (Yusuf \& Albanawi, 2016). The localized effect of entrepreneurship is to elevate the level of society in creating the job opportunity for the local community and at the same time utilizing local resources and raw materials, reducing poverty, creating wealth, and having the ability to identify socio-economic needs to benefit the society (Tersoo, 2013).

The importance of entrepreneurship is noticeable, but it may have a different meaning and image for those in the low-income and underprivileged communities. Government and development agencies are forceful entrepreneurship toward low-income people through programs, trainings, and financial assistance (Bin Yusoff, Zainol, F,A, 2012). These communities tend to involve in informal activities, and involved in multiple types of business activities (Rosa, Kodithuwakku, \& Balunywa, 2006). At times, informal sectors are not included in the entrepreneurship definition, but Spring and McDade (1998) provided a broader definition and included the small-scale informal economy with the large-scale operators from the formal economy. However, the act of being involved in an entrepreneurial activity is a challenge for the low-income group compared to those above the poverty line since day-to-day survival with limited resource is tough enough without the stress of entrepreneurship. Though, entrepreneurship is still establish to be relevant, focused, and important to individuals and organizations involved in poverty alleviation activities (DyalChand \& Rowan, 2014).

In the Malaysian scenario, entrepreneurship is highly regarded and accepted as the backbone of economic development as well as an employment creating agent, wealth creator, poverty alleviator, and many more. Entrepreneurship is a tool for poverty eradication and the means for uplifting the low-income and underprivileged people in Malaysia which has been true since Malaysian Independence in 1957 and continued to be true when followed by the New Economic Policy in 1971-1990 (Hamdam, Othman \& Hussin, 2012). Domestically, the Malaysian government and development agencies are promoting entrepreneurship through micro, small, and medium establishments which are equipped with entrepreneurial training and guidance, and financial support. Various agencies such as Amanah Ikthiar Malaysia, Majlis Amanah Rakyat (MARA) under the Ministry of Rural and Regional Development, and TEKUN under the Ministry of Entrepreneur and Co-Operative Development are among those involved in the formulation, creation, implementation, support, and facilitation of 
entrepreneur development programs at the federal and state levels. An empirical study by Hussain and Bhuiyan (2014) discovered that micro, small, and medium establishments were directly correlated to economic growth and poverty alleviation since this training and infrastructure gives the low-income groups a chance to grow out of poverty.

The phenomenon of entrepreneurship is considered to turn around the entrepreneur, the organization, and the link between these two (Omrane \& Fayolle, 2011). This sets the precedence for the stream of research on entrepreneurs, and their personality traits, based on psychological aspects which address the difference between entrepreneurs and nonentrepreneurs, and the reasons an individual decides to venture into business while others do not (Ho \& Barnes, 2012). An individual's entrepreneurial traits are anticipated to affect his/her decisions when starting from an idea of whether to start a business, to daily decisionmaking, then on to how the individual manages, and his/her views on the entrepreneurial process as a whole (Al Mamun, A., Kumar, N., Ibrahim, M. D., \& Bin Yusoff, M. N. H., 2017). Thus, it is important to study psychological traits in relation to the aspects of entrepreneurship. At the organizational level, entrepreneurial traits among employees contribute to the performance and competitiveness of the firm (Serinkan et al., 2013) while, even at the general population level, entrepreneurial related personality traits increase the level of work satisfaction (Rus \& Sandu, 2013).

These relationships between entrepreneurial traits and the entrepreneurial phenomenon is thus regarded as crucial in determining what makes an individual endeavor into an entrepreneur and how he or she moves along the entrepreneurial process. Based on the importance of studying the entrepreneurial traits in entrepreneurs and entrepreneurship, and their significant relationship to social and economic development, this study therefore examines the level of entrepreneurial orientation among the low-income household heads in Kelantan, Malaysia.

\section{LITERATURE REVIEW}

Entrepreneurial startups have been noted to be at their highest levels over the last few decades (Gartner \& Shane, 1995). This has motivated researchers and policy makers to try to understand the factors that influence entrepreneurial activity which has made entrepreneurship an important field of study (Thomas \& Mueller, 2000). As a result, studies which focus on business startups from the aspects of supply and demand have been widely carried out. The supply aspect looks into the entrepreneur's character while the demand aspect views the environmental basis of the organization's formation (Nguyen \& Phan, 2014). In addition, studies identifying the unique characteristics of entrepreneurs compared to non-entrepreneurs have been widely carried out (Bolton \& Thompson, 2004). Entrepreneurs are believed to have a set of characteristics that distinguish them from the rest which was noted by Fillion (2000) when he identified and listed the 24 most commonly used entrepreneurial characteristics, i.e., strategic style, management style, attitude to risk, attitude in interpersonal relations, need for security, need for power, innovation, ability to adapt, independence, delegation, vision, commitment, self-concept, systematic root, relations system, purpose, locus of control, creativity, need for achievement, need for recognition, attitude to growth, attitude to profits, leadership style, and decision making style. For the purpose of this study, limited components such as tolerance for ambiguity, need for achievement, vision, and persistence of entrepreneurial traits, have been included.

Tolerance of ambiguity - Tolerance for ambiguity is defined as the tendency to perceive ambiguous situations as desirable (Budner, 1962). An ambiguous situation is regarded as when a person is provided with inadequate, complex, or contradictory information (Norton, 1975). A person with low tolerance for ambiguity will try to avoid ambiguous situations, and 
might feel stressed and pressured in such situations. On the other hand, people with a high tolerance for ambiguity are more comfortable with an ambiguous situation, and at times regard it as interesting and desirable. Entrepreneurs are expected to be high in tolerance for ambiguity as they are more risk prone and deal with continuous uncertainty (McMullen \& Shepherd, 2006). A study which looked at single mother entrepreneurs in Malaysia found that tolerance of ambiguity was significantly related to entrepreneurial passion together with risk taking where surprisingly, need for achievement was not significant (Ismail, et al., 2015). Another study looked at entrepreneurial intention among senior university students in China and found that tolerance for ambiguity positively impacts entrepreneurial intention (Raheem \& Honglin, 2015).

Need for achievement - Need for achievement is an individual's burning desire to achieve something and tie his or her objective to daily activities to remain focused (Gorman, 2004). As such, people with a high need for achievement are surrounded by similarly minded people, because people who are constantly surrounded by people with a high need for achievement are more likely to work hard to succeed (Bosse, 2015). Individuals with this characteristic are more comfortable when choosing moderately difficult tasks which challenge them and leads to a better probability of success with excellence. Striving for excellence, being concerned about performance, and aiming for higher achievement can be huge motivating factors for a person's success.

Vision - Vision is defined as a mental image of what a person wants to achieve (Bass \& Stogdill, 1990) which acts as a general goal, thus it is considered a motivational factor. Entrepreneurs who are visionary are those who have a goal and have a predetermined target to achieve. Vision is one of the three motivational factors that influence business performance, while goals and self-efficacy are the other two (Bandura, 1997). The study by Baum and Locke (2004) looked at venture growth based on a longitudinal approach which found that an entrepreneur's communicated vision had a significant effect on venture growth. It was even found that vision and goals had a significant relationship. The study highlighted that having a vision alone is not enough, as the entrepreneur's vision needs to be communicated to better predict the venture growth. In the area of sustainable entrepreneurship, visionary individuals go into business start-ups with the mindset of "changing the world" and consider business the means to achieve this end. Their sustainability related motivation creates positive effects and has been found to be high in product or service quality, long-term focus, need-orientation, and actions based on sustainability principles (Bergset \& Fichter, 2015).

Persistence - Persistence is the voluntary continuation of a course of action even when faced with obstacles. Persistence is considered key to venture success and the unofficial motto of entrepreneurship (Holland, 2008). Persistence makes an entrepreneur remain focused in the venture regardless of the difficulties faced. Steers, Mowday, and Shapiro (2004) classified persistence as a form of motivation, which is related to the willingness to do or continue doing. Persistence is therefore a motivational factor to continue doing something that has been started, and doing it even in situations where there is an opposing force. In the works of Holland (2008), financial returns, switching costs, and non-financial benefits were identified as factors leading to entrepreneurial persistence.

\section{RESEARCH METHODOLOGY}

This study empployed a cross-sectional design in identifying the level of entrepreneurial traits across districts, gender, education, occupations, and experience levels in Kelantan, Malaysia. The population involved in this study were the low-income households of the poorest state in Peninsular Malaysia, i.e., Kelantan which registered under 'Majlis Agama Islam Dan Adat Istiadat Melayu Kelantan (ASNAF)'. This study then choose four districts in Kelantan, which 
comprise of Bachok, Tumpat, Jeli, and Gua Musang. A total of 3,090 low-income households form the population across the four districts, i.e., Bachok (1394), Tumpat (1257), Jeli (233), and Gua Musang (206). Since this study intended to compare across locations and other antecendents, it randomly selected 800 low-income respondents with a total of 200 respondents from each location. Data was collected through paper based survey.

The questionnaire was translated into Malay and checked for inter-translator consistency. The questionnaire was developed based on the review of the existing entrepreneurship indices and tested through a pilot survey. The instrument was enhanced based on the comments and feedback from the pilot survey. This study used a five-point Likert scale ranging from one which denotes "strongly disagree" to five which denotes "strongly agree" to avoid confusion and biases of fatigue in longer scales. The research instrument was adapted and modified from past studies and an existing entrepreneurship index (Norasmah, 2006; Noraishah, 2003).

\section{RESEARCH FINDINGS}

In order to conduct a study across districts, gender, education levels, occupations, and experience levels, to compare entrepreneurial traits, this study collected quantitative data from a total of 800 low-income household heads from the state of Kelantan, Malaysia. Among them, $544(68.0 \%)$ household heads are women and $256(32.0 \%)$ are men. A high proportion of them, $292(36.5 \%)$ are more than 55 years old, followed by $250(31.3 \%)$ people between the ages of 31 and 45. Among them, 78 (9.8\%) household heads reported not having any children, 297 (37.1\%) reported having 4 to 6 children, and $5(0.6 \%)$ reported having more than 12 children. Among the respondents, 423 (52.9\%) reported having earlier experience in managing a business, $241(30.1 \%)$ of them had experience of less than 5 years, while 42 $(5.3 \%)$ of them had experience operating a business for more than 21 years. A majority of them, 570 or $71.3 \%$ reported an interest in venturing into a business, while $202(25.3 \%)$ have no interest in opening a business, and $28(3.5 \%)$ reported being uncertain about whether or not to open a business.

Cronbach's Alpha explains the indicators' inter-correlations, which estimate the reliability of the indicators used. The Shapiro-Wilk's test $(p>.05)$ explains the normality of data distribution. Based on Table 1, Cronbach's Alpha values for all items, i.e., self-improvement, self-confidence, openness to change, pull factors, need of achievement, and motivation, are more than 0.7 , which means all the items are reliable. The $p$ value for all the items are less than .005 , which means that the data is not normally distributed. This study therefore used the non-parametric Independent-Samples-Kruskal-Wallis Test to assess distribution.

Based on the results presented in Table 2, there is a statistically significant difference in the distribution of tolerance of ambiguity, need for achievement, visionary, persistence, and psychological traits across the four districts of Bachok, Tumpat, Jeli, and Gua Musang. Tolerance of ambiguity is noted to be the highest in Gua Musang with a mean rank of 460.03 and the lowest in Jeli with a mean rank of 270.87. Need for achievement is noted to be the highest in Tumpat with a mean rank of 485.84 and the lowest in Jeli with a mean rank of 216.17. Visionary is the highest in Gua Musang with a mean rank of 535.91 and the lowest in Jeli with a mean rank of 237.55. Persistence is the highest in the district of Tumpat with a mean rank of 512.55 and the lowest in the district of Jeli with a rank of 249.28. Overall, the distribution of psychological traits among the low-income household heads is the highest in the district of Gua Musang with a mean rank of 512.19 and the lowest in the district of Jeli with a mean rank of 215.82 . 
Table 1. Descriptive, Normality, and Reliability

\begin{tabular}{cccccc}
\hline & Items & Mean & SD & $\begin{array}{c}\text { Shapiro-Wilk } \\
\text { (p value) }\end{array}$ & CAlpha \\
\hline TA & 5 & 3.2313 & .97028 & 0.000 & 0.903 \\
NA & 5 & 3.0525 & 1.0822 & 0.000 & 0.863 \\
VS & 4 & 2.8500 & 1.2316 & 0.000 & 0.873 \\
PE & 6 & 2.9950 & 1.0422 & 0.000 & 0.892 \\
PT & 20 & 2.3525 & 1.0593 & 0.000 & 0.954 \\
\hline Note: TA: Tolerance of ambiguity; NA: Need for achievement; VS: Visionary; PE: Persistence; PT: Psychological Traits
\end{tabular}

Table 2 Motivation - Cross District Analysis

\begin{tabular}{cccccc}
\hline & $\begin{array}{c}\text { Mean Rank } \\
\text { (Bachok) }\end{array}$ & $\begin{array}{c}\text { Mean Rank } \\
\text { (Tumpat) }\end{array}$ & $\begin{array}{c}\text { Mean Rank } \\
\text { (Jeli) }\end{array}$ & $\begin{array}{c}\text { Mean Rank } \\
\text { (Gua Musang) }\end{array}$ & $\begin{array}{c}\text { Kruskal } \\
\text { Wallis Test }\end{array}$ \\
\hline TA & 440.13 & 430.97 & 270.87 & 460.03 & .000 \\
NA & 440.30 & 485.84 & 216.17 & 459.70 & .000 \\
VS & 433.86 & 394.69 & 237.55 & 535.91 & .000 \\
PE & 427.74 & 512.55 & 249.28 & 412.44 & .000 \\
PT & 449.71 & 424.28 & 215.82 & 512.19 & .000 \\
\hline \multicolumn{2}{l}{ Note: TA: Tolerance of ambiguity; NA: Need for achievement; VS: Visionary; PE: Persistence; PT: Psychological Traits }
\end{tabular}

As presented in Table 3, the distribution of tolerance of ambiguity, need for achievement, visionary and psychological traits is the same for both genders. Persistence is noted to have a statistically significant difference in the distribution for gender, where the female low-income household heads reported to have a higher level of persistence with a mean rank of 412.67 than males who scored a mean rank of 374.63. Overall, the distribution of psychological traits is the same between male and female household heads.

Table 3 Motivation - Cross Gender Analysis

\begin{tabular}{cccc}
\hline & Mean Rank (Male) & $\begin{array}{c}\text { Mean Rank } \\
\text { (Female) }\end{array}$ & $\begin{array}{c}\text { Kruskal Wallis } \\
\text { Test }\end{array}$ \\
\hline TA & 389.36 & 405.74 & .313 \\
NA & 405.11 & 398.33 & .682 \\
VS & 408.87 & 396.56 & .466 \\
PE & 374.63 & 412.67 & .023 \\
PT & 405.42 & 398.19 & .667 \\
\hline
\end{tabular}

Note: TA: Tolerance of ambiguity; NA: Need for achievement; VS: Visionary; PE: Persistence; PT: Psychological Traits

As illustrated in Table 4, there is a statistically significant difference in the distribution of tolerance of ambiguity, need for achievement, visionary, persistence, and psychological traits across education levels of low-income household heads in Kelantan. Tolerance of ambiguity is noted to be the highest among those who answered "others" with a mean rank of 472.67 and the lowest among household heads who reported to have never attended school with a mean rank of 265.49. Need for achievement is noticed to be the highest among SPM holders with a mean rank of 464.55 and the lowest among household heads who reported to have never attended school with a mean rank of 249.89. Visionary is the highest among SPM holders with a mean rank of 443.19 and the lowest among household heads who reported to have never attended school with a mean rank of 292.56. Persistence is the highest among SPM holders with a mean rank of 467.65 and the lowest among household heads who reported to have never attended school with a mean rank of 258.44. Overall, the distribution of psychological traits among the low-income household heads is the highest among the PMR leavers with a mean rank of 448.14 and the lowest among household heads who reported to have never attended school with a mean rank of 281.69. 
Mohd Nor Hakimin B Yusoff, Fakhrul Anwar Zainol, Mohamad B Ismail, Abdullah Al-Mamun,

Tengku Md Azizudin Tuan Mahmood and Rooshihan Merican Abdul Rahim Merican

Table 4 Motivation - Cross Education Level

\begin{tabular}{lccccccc}
\hline & $\begin{array}{c}\text { Mean } \\
\text { Rank } \\
\text { (Std. Six) }\end{array}$ & $\begin{array}{c}\text { Mean } \\
\text { Rank } \\
\text { (PMR) }\end{array}$ & $\begin{array}{c}\text { Mean } \\
\text { Rank } \\
\text { (SPM) }\end{array}$ & $\begin{array}{c}\text { Mean Rank } \\
\text { (Religious) }\end{array}$ & $\begin{array}{c}\text { Mean Rank } \\
\text { (No School) }\end{array}$ & $\begin{array}{c}\text { Mean Rank } \\
\text { (Others) }\end{array}$ & $\begin{array}{c}\text { Kruskal } \\
\text { Wallis Test }\end{array}$ \\
\cline { 2 - 8 } TA & 408.35 & 434.36 & 448.25 & 435.75 & 265.49 & 472.67 & .000 \\
NA & 395.40 & 439.82 & 464.55 & 415.42 & 249.89 & 431.40 & .000 \\
VS & 393.92 & 437.21 & 443.19 & 364.58 & 292.56 & 389.23 & .000 \\
PE & 376.07 & 440.81 & 467.65 & 420.75 & 258.44 & 452.63 & .000 \\
PT & 393.83 & 448.14 & 440.07 & 429.17 & 281.69 & 437.97 & .000 \\
\hline \multicolumn{5}{l}{ Note: TA: Tolerance of ambiguity; NA: Need for achievement; VS: Visionary; PE: Persistence; PT: Psychological Traits }
\end{tabular}

Table 5 Motivation - Cross Occupation

\begin{tabular}{cccccccc}
\hline & $\begin{array}{c}\text { Mean } \\
\text { Rank } \\
\text { (Labor) }\end{array}$ & $\begin{array}{c}\text { Mean Rank } \\
\text { (Fisherman) }\end{array}$ & $\begin{array}{c}\text { Mean Rank } \\
\text { (Own } \\
\text { business) }\end{array}$ & $\begin{array}{c}\text { Mean } \\
\text { Rank } \\
\text { (Farmer) }\end{array}$ & $\begin{array}{c}\text { Mean Rank } \\
\text { (Un-employed) }\end{array}$ & $\begin{array}{c}\text { Mean Rank } \\
\text { (Others) }\end{array}$ & $\begin{array}{c}\text { Kruskal } \\
\text { Wallis } \\
\text { Test }\end{array}$ \\
\hline TA & 474.45 & 325.33 & 471.49 & 454.54 & 320.38 & 428.68 & .000 \\
NA & 488.42 & 385.13 & 464.48 & 394.42 & 330.42 & 424.55 & .000 \\
VS & 496.79 & 298.30 & 437.77 & 429.63 & 336.67 & 477.41 & .000 \\
PE & 479.96 & 421.50 & 468.14 & 348.94 & 330.21 & 443.09 & .000 \\
PT & 478.06 & 324.13 & 442.22 & 421.43 & 340.44 & 460.84 & .000 \\
\hline \multicolumn{2}{r}{ Note: TA: Tolerance of ambiguity; NA: Need for achievement; VS: Visionary; PE: Persistence; PT: Psychological Traits }
\end{tabular}

Table 6 Motivation - Cross Experience Level

\begin{tabular}{cccccccc}
\hline & $\begin{array}{c}\text { Mean } \\
\text { Rank } \\
<\mathbf{5} \text { years })\end{array}$ & $\begin{array}{c}\text { Mean } \\
\text { Rank } \\
(\mathbf{6}-\mathbf{1 0})\end{array}$ & $\begin{array}{c}\text { Mean } \\
\text { Rank } \\
(\mathbf{1 1}-\mathbf{1 5})\end{array}$ & $\begin{array}{c}\text { Mean } \\
\text { Rank } \\
(\mathbf{1 6 - 2 0})\end{array}$ & $\begin{array}{c}\text { Mean Rank } \\
\mathbf{( > 2 1} \text { years) }\end{array}$ & $\begin{array}{c}\text { Mean Rank } \\
\text { (No experience) }\end{array}$ & $\begin{array}{c}\text { Kruskal } \\
\text { Wallis Test }\end{array}$ \\
\hline TA & 445.65 & 474.06 & 447.16 & 442.34 & 444.24 & 343.80 & .000 \\
NA & 451.23 & 487.95 & 397.93 & 371.41 & 462.17 & 343.89 & .000 \\
VS & 448.79 & 451.90 & 402.90 & 365.05 & 396.61 & 360.59 & .000 \\
PE & 441.89 & 500.05 & 413.30 & 385.14 & 496.62 & 341.12 & .000 \\
PT & 430.80 & 456.19 & 411.61 & 385.25 & 431.80 & 365.24 & .001 \\
\hline \multicolumn{5}{l}{ Note: TA: Tolerance of ambiguity; NA: Need for achievement; VS: Visionary; PE: Persistence; PT: Psychological Traits }
\end{tabular}

Table 5 highlight the results for distribution of tolerance of ambiguity, need for achievement, visionary, persistence, and psychological traits across different types of occupation of low-income household heads in the state of Kelantan. It was discovered that tolerance of ambiguity, need for achievement, visionary, persistence, and psychological traits are all significantly different among laborers, fishermen, individuals running their own business, farmers, unemployed, and those who answered "others". Tolerance of ambiguity is noted to be the highest among laborers with a rank of 474.45 and the lowest among the unemployed with a mean rank of 320.38. Need for achievement is noted to be the highest among laborers with a mean rank of 488.42 and the lowest among the unemployed with a mean rank of 330.42. Visionary is the highest among laborers with a mean rank of 496.79 and the lowest among fishermen with a mean rank of 298.30. Persistence is found the highest among laborers with a mean rank of 479.96 and the lowest among the unemployed with a mean rank of 330.21. Overall, the distribution of psychological traits among the low-income household heads is the highest among laborers with a mean rank of 478.06 and the lowest among household heads who are fishermen with a mean rank of 324.13.

Based on the results highlighted in Table 6, there is a statistically significant difference in the distribution of tolerance of ambiguity, need for achievement, visionary, persistence, and psychological traits across the experience levels of low-income household heads in Kelantan. Tolerance of ambiguity is noted to be the highest among those with 6 to 10 years of experience with a mean rank of 474.06 and the lowest among those with no experience with a mean rank of 343.80. Need for achievement is noted to be the highest among those with 6 to 
10 years of experience with a mean rank of 487.95 and the lowest among those with no experience with a mean rank of 343.89. Visionary is the highest among those with 6 to 10 years of experience with a mean rank of 451.90 and the lowest among those with no experience with a mean rank of 360.59. Persistence is the highest among those with 6 to 10 years of experience with a mean rank of 500.05 and the lowest among those with no experience with a mean rank of 341.12. Overall, the distribution of psychological traits among the low-income household heads is the highest among those with 6 to 10 years of experience with a mean rank of 456.19 and the lowest among those with no experience with a mean rank of 365.24 .

\section{CONCLUSION AND RECOMMENDATION}

Entrepreneurial traits are one of the most researched elements in entrepreneurship studies since it influences entrepreneurial activities. Entrepreneurial traits are regarded as the differentiator between entrepreneurs and non-entrepreneurs. Traits are widely studied as they are linked to various levels and stages of the entrepreneurial process. The findings propose that the distribution of psychological traits is more balanced across male and female lowincome household heads. However, it is noted that psychological traits are low among lowincome household heads in Jeli compared to Bachok, Tumpat, and Gua Musang. On the other hand, psychological traits levels are found to be low among low-income household heads who did not attend school and evidently, motivation is low as well among household heads who were fishermen. At the experience level, a significant difference is encountered where household heads with no experience showed a low level of the psychological traits. Components such as tolerance of ambiguity, need for achievement, vision, and persistence should be focused on, to increase, among low-income household heads. Leaders and policy makers should implement policies or programs to increase psychological traits in general, and specifically among low-income household heads in the district of Jeli, those who have never attended school, fishermen, and those with no experience. Nevertheless, the reason for the unequal distribution is not determined in this research; future studies may considered to emphasis on the reason for the unequal distribution as well as the key factors which contribute to the low level of psychological traits in these areas.

Funding: This research was funded by the Ministry of Higher Education, Malaysia under the grant entitled "Developing a Comprehensive Rural Entrepreneurship Model for Poverty Eradication (REMODE)" (R/NRGS/A01.00/00047A/006/2014/000149).

\section{REFERENCES}

[1] Al Mamun, A., Kumar, N., Ibrahim, M. D., \& Bin Yusoff, M. N. H. (2017). Validating the measurement of entrepreneurial orientation. Economics and Sociology, 10(4), 51-66.

[2] Bandura, A. (1997). Self-efficacy: The exercise of control. New York: Freeman.

[3] Bass, B. M., \& Stogdill, R. M. (1990). Bass \& Stogdill's handbook of leadership: Theory, research, and managerial implications. New York: Free Press.

[4] Baum, J. \& Locke, E. (2004). The Relationship of Entrepreneurial Traits, Skill, and Motivation to Subsequent Venture Growth. Journal of Applied Psychology, 89(4), 587-598.

[5] Bergset, L. \& Fichter, K. (2015). Green start-ups - a new typology for sustainable entrepreneurship and innovation research. Journal of Innovation Management, 3(3), 118-144.

[6] Bin Yusoff, M. N. H., Zainol, F. A., \& Wan Nadzrol (2012). Assessing the impact of knowledge of government business support services on propensity of new graduates to venture into business. International Journal of Business and Management, 7(16), 106 
Mohd Nor Hakimin B Yusoff, Fakhrul Anwar Zainol, Mohamad B Ismail, Abdullah Al-Mamun, Tengku Md Azizudin Tuan Mahmood and Rooshihan Merican Abdul Rahim Merican

[7] Bolton, B \& Thompson, J. (2004). Entrepreneurs: talent, temperament, technique, 2nd ed. Oxford: Elsevier Butterworth-Heinemann

[8] Bosse, A. (2015). Need for Achievement ( $\mathrm{n}$ Ach) and Occupation. The Huron University College Journal of Learning And Motivation, 53(1), 1-16.

[9] Budner, N. (1962). Intolerance of ambiguity as a personality variable1. Journal of Personality, 30(1), 29-50.

[10] Dyal-Chand, R. \& Rowan, J. (2014). Developing Capabilities, Not Entrepreneurs: A New Theory for Community Economic Development. Hofstra Law Review, 42(3), 839-903.

[11] Filion, L. (2000). Entrepreneurial typologies (pp. 163-172). Montréal: École des hautes études commerciales, Chaire d'entrepreneurship Maclean Hunter.

[12] Gartner, W. \& Shane, S. (1995). Measuring entrepreneurship over time. Journal of Business Venturing, 10(4), 283-301.

[13] Gorman, P. (2004). Motivation and Emotion. (1st ed., pp. 62-64). New York, NY: Routledge.

[14] Hamdan, H., Othman, P., \& Hussin, W. (2012). Is microfinance program in Malaysia really effective in helping the poor? World Review of Business Research, 2(2), 79-97.

[15] Ho, P. \& Barnes, L. (2012). An Examination of the Traits of Successful Entrepreneurs in Hong Kong: The PAST Model. Journal of Modern Accounting and Auditing, 8(8), 1237-1245.

[16] Holland, D. (2008). Never, never, never give in? Understanding the entrepreneur's decision to persist in the face of adversity. Frontiers of Entrepreneurship Research, 28(6), 1-16.

[17] Hussain, M. \& Bhuiyan, A. (2014). Entrepreneurship Development and Poverty Alleviation: An Empirical Review. Journal of Asian Scientific Research, 4(10), 558-573

[18] Ismail, I., Rahim, N., Kamal, M., Mat, R., \& Husin, N. (2015). Investigating the Needs for Achievement, Risk Taking and Tolerance for Ambiguity toward Entrepreneurial Passion among Single Mother Entrepreneur in Malaysia. Procedia Economics and Finance, 31, 110116.

[19] McMullen, J. \& Shepherd, D. (2006). Entrepreneurial Action And The Role Of Uncertainty In The Theory Of The Entrepreneur. Academy of Management Review, 31(1), 132-152.

[20] Nguyen, M. \& Phan, A. (2014). Entrepreneurial Traits and Motivations of the Youth - an Empirical Study in Ho Chi Minh City - Vietnam. International Journal of Business and Social Science, 5(5), 53-62.

[21] Noraishah, B. (2003). Entrepreneurs psychometric index, available at http://www.piken.com.my (Accessed: 22 May, 2016).

[22] Norasmah, O. (2006). Indeks keusahawanan remaja Malaysia, manual \& instrumen.

[23] Norton, R. (1975). Measurement of Ambiguity Tolerance. Journal of Personality Assessment, 39(6), 607-619

[24] Omrane, A. \& Fayolle, A. (2011). Entrepreneurial competencies and entrepreneurial process: a dynamic approach. International Journal of Business and Globalization, 6(2), 136.

[25] Raheem Bux, S. \& Honglin, Y. (2015). Analyzing the Impact of the Psychological Characteristics on Entrepreneurial Intentions among University Students. Advances in Economics and Business, 3(6), 215-224.

[26] Rosa, P., Kodithuwakku, S., \& Balunywa, W. (2006). Entrepreneurial Motivation In Developing Countries: What Does 'Necessity' and 'Opportunity' Entrepreneurship Really Mean? Frontiers of Entrepreneurship Research, 26(20), 1-14.

[27] Rus, M. \& Sandu, M. (2013). Personality Factors and Job Satisfaction Levels in Military Staff Employed on a Contract basis. Procedia - Social and Behavioral Sciences, 92, 814-819. 
[28] Serinkan, C., Kaymakçi, K., Arat, G., \& Avcik, C. (2013). An Empirical Study on Intrapreneurship: In A Service Sector in Turkey. Procedia - Social and Behavioral Sciences, 89, 715-719.

[29] Spring, A. \& McDade, B. (1998). Entrepreneurship in Africa: traditional and contemporary paradigms. In African Entrepreneurship: Theory and Reality (1st ed., pp. 1-34). University Press of Florida.

[30] Steers, R., Mowday, R., \& Shapiro, D. (2004). The Future Of Work Motivation Theory. Academy of Management Review, 29(3), 379-387.

[31] Tersoo, K. (2013). The Impact of Women Entrepreneurship on Economic Growth In Benue State-Nigeria. IOSR Journal of Business and Management, 13(1), 7-12.

[32] Thomas, A. \& Mueller, S. (2000). A Case for Comparative Entrepreneurship: Assessing the Relevance of Culture. Journal of International Business Studies, 31(2), 287-301.

[33] Yusuf, N. \& Albanawi, N. (2006). The Role of Entrepreneurship in Economic Development in Saudi Arabia. Business and Economics Journal, 7(01), 1-5. 